\title{
Some Limitations in the Use of the Air Picnometer for Soil-Porosity, Soil-Moisture, and Particle- Density Determinations
}

\author{
José Vicente-Chandler, Servando Silva, and Jacinto Figarella ${ }^{1}$
}

\section{INTRODUCTION}

The air picnometer has been rather widely used in determining the porosity of soils $(4,6,7,8,11,12)^{2}$. Some investigators $(4,7,11)$ have proposed using the air picnometer to determine soil particle density and soil-moisture content. Jamison (3) has recently shown that this instrument cannot be used accurately to determine the particle density of dry soil since gaseous adsorption occurring on the surface of dry soil colloids can introduce a considerable error in these determinations.

\section{OBJECTIVE}

The purpose of this paper is to present the results of a study aimed at determining the adaptability of the bellows-type air picnometer to soilporosity, soil-moisture, and particle-density measurements as compared with standard methods. The possibility of using moist soil in picnometric determinations to avoid the error introduced by gaseous adsorption on dry colloids was explored.

\section{METHODS USED}

Precautions were taken to make sure that the measurements with the air picnometer were as accurate as possible. The apparatus was constantly checked for leaks and was recalibrated periodically, since some variation was found to occur with usage. Readings were taken exactly 30 seconds after complete compression of the bellows. Different curves were prepared for use at varying atmospheric pressures.

\section{PARTICLE-DENSITY DETERMINATIONS}

Determinations were made by the standard picnometer-bottle method using both water and nitrobenzene. Oven-dried soil cooled in a desiccator was used. To insure complete saturation of all voids with liquid the procedure recommended by Smith (10) was followed.

Gentle boiling at $80^{\circ} \mathrm{C}$. in a partial vacuum was tested as a further means

1 Project Supervisor, Physical Science Aid, and Soil Scientist, respectively, of a cooperative Project between the Agricultural Experiment Station of the University of Puerto Rico, Río Piedras, P.R., and the Agricultural Research Service of the U.S. Department of Agriculture.

2 Numbers in parentheses refer to Literature Cited, p. 188. 
of insuring complete saturation of the soil pores with both nitrobenzene and water. Essentially the same results were obtained as with the method recommended by Smith.

The particle density of the soils studied was also calculated from determinations made with the air picnometer on moist and on oven-dried soil cores. In the former case the necessary corrections for the space occupied by water were made by calculating the volume of water from the loss in weight of the cores upon oven-drying and assuming the density of water to be 1 .

\section{POROSITY DETERMINATIONS}

Undisturbed 3-inch $\times 3$-inch (348 cc.) soil cores were used in these studies. Bulk densities were calculated from the dry weight of soil in the cores. The total porosity of the cores was calculated from their bulk densities with a particle density of 2.56 assumed.

The total porosity of the cores was determined with the air picnometer by measurements on oven-dried samples and on cores as brought from the field. In the latter case the volume of water (determined by loss in weight upon oven drying) was taken into consideration in calculating the total porosity of the cores.

\section{SOIL-MOISTURE DETERMINATIONS}

The moisture content of 26 undisturbed soil cores from three soil series was determined with the air picnometer, and by loss in weight upon ovendrying. The following formula was used to calculate the soil moisture content of the soil cores from measurements with the air picnometer:

Percentage of moisture by weight

$$
=\frac{100 \text { (part. den. }(\text { cc. solids }+ \text { liquid })-(\text { gm. solids }+ \text { liquid })}{\text { part. den. } \text { (gm. solids }+ \text { liquid })-(\text { cc. solids }+ \text { liquid })}
$$

\section{OTHER DETERMINATIONS}

The above studies indicated that considerable air dissolved in soil moisture in the course of determinations with the air picnometer on wet soils. This caused appreciable errors. An attempt was therefore made to determine the effect of soil-moisture content on picnometric determinations. The soil cores studied were saturated with water and then allowed to dry slowly in air. They were weighed periodically and picnometric determinations were made. The cores were finally oven-dried, cooled, weighed, and determinations made with the air picnometer. From these data the apparent 
total porosity and quantity of air "sorbed"3 by the soil samples at various moisture contents were calculated.

\section{EFFECTS OF AIR-WATER INTERFACE}

From the above study it appeared likely that area of air-water interface was one of the main factors affecting the extent of gaseous solution in soil moisture. In an attempt to test this hypothesis, Domby ${ }^{4}$ carried out a study with two soils to determine the effect of soil structure and air content on the apparent volume of soil-plus-water, as measured by the air picnometer. Samples having equal quantities of soil and water were compressed to different overall volumes, thus varying both structure and the amount of air-water interface.

\section{SOILS USED}

Four soil types were included in this study. Catalina clay is a deep-red, acid kaolinitic soil (latosol) derived from andesitic tuff and tuffaceous shale. Coto and Fajardo clays are similar soils derived from hard limestone and outwash from shale hills, respectively. Toa loam is a slightly acid, deep, alluvial soil with predominantly expanding lattice-type clay minerals.

\section{RESULTS}

Results of particle-density determinations on samples of three soils by the methods described above, together with some related soil properties, are shown in table 1. The particle densities obtained in nitrobenzene varied little from the value (2.65) frequently assumed for most soils. The values obtained with water were higher in all cases. Those obtained by the airpicnometer method with both moist and oven-dry soils were much too high in all cases.

Total-porosity values of the soil cores as determined by the methods described are shown in table 2 . The values calculated from bulk-density and particle-density data (assuming a value of 2.65 for particle density) are considered to be correct. The porosity values obtained by the air-picnometer method with both moist and dry soil cores were too high in all cases.

The results of the soil-moisture determinations indicate that the values obtained with the air picnometer were, with three exceptions, within 5 percent of the values determined by oven-drying.

Table 3 shows the results of the study to determine the effect of variable moisture content on picnometric determinations. At all moisture levels the

3 This term is herein used to indicate air adsorbed on dry colloids, dissolved in soil moisture, or otherwise unaccounted for.

- Charles W. Domby, deceased, formerly Soil Scientist, Agricultural Research Service, USDA. 
total porosities of the cores, as determined with the air picnometer, were much higher than the calculated values. Considerable air was "sorbed" at all moisture levels. There was no apparent relationship between moisture content and total porosity or amount of "sorbed" air.

The results of the study to determine the effect of percentage of air volume and soil structure on picnometric determinations are summarized in table 4 . The data indicate that as wet soils are compressed, decreasing their air content and air-water interface, there is less "sorption" of air, and picnometric determinations are therefore more precise.

TABLe 1.-The particle density of several soils of Puerto Rico as determined by various methods

\begin{tabular}{|c|c|c|c|c|c|c|c|}
\hline \multirow[b]{2}{*}{ Soil and sample No. } & \multirow[b]{2}{*}{ Clay } & \multirow[b]{2}{*}{$\begin{array}{l}\text { Organic } \\
\text { Matter }\end{array}$} & \multicolumn{5}{|c|}{ Particle density as determined by methods indicated } \\
\hline & & & $\begin{array}{c}\text { Picno- } \\
\text { meter } \\
\text { bottle and } \\
\text { nitro- } \\
\text { benzene }\end{array}$ & $\begin{array}{c}\text { Picno- } \\
\text { meter } \\
\text { bottle and } \\
\text { water }\end{array}$ & $\begin{array}{c}\text { Air picno- } \\
\text { meter with } \\
\text { oven-dried } \\
\text { soil }\end{array}$ & $\begin{array}{c}\text { Air picno- } \\
\text { meter with } \\
\text { moist } \\
\text { soil }\end{array}$ & $\begin{array}{c}\text { Moisture } \\
\text { by } \\
\text { volume }\end{array}$ \\
\hline & Percent & Percent & & & & & Percent \\
\hline \multicolumn{8}{|l|}{ Catalina: } \\
\hline 1 & 46.2 & 2.61 & 2.66 & 2.71 & 3.32 & 3.11 & 44.2 \\
\hline 2 & 64.2 & 4.20 & 2.61 & 2.75 & 3.26 & 3.05 & 42.3 \\
\hline 3 & 54.3 & 3.48 & 2.63 & 2.70 & 3.47 & 3.16 & 42.6 \\
\hline 4 & 55.6 & 3.94 & 2.65 & 2.74 & 3.37 & 3.04 & 43.2 \\
\hline $\mathbf{5}$ & 46.1 & 3.81 & 2.66 & 2.71 & 3.34 & 2.94 & 30.2 \\
\hline \multicolumn{8}{|l|}{ Coto: } \\
\hline 1 & 72.0 & 3.20 & 2.64 & 2.74 & 3.10 & 2.92 & 30.0 \\
\hline 2 & 75.0 & 3.01 & 2.61 & 2.73 & 2.98 & 2.88 & 24.9 \\
\hline 3 & 68.0 & 3.50 & 2.60 & 2.72 & 3.32 & 3.26 & 22.7 \\
\hline \multicolumn{8}{|l|}{ Toa: } \\
\hline 1 & 30.8 & 4.58 & 2.62 & 2.64 & 3.33 & 3.06 & 49.4 \\
\hline 2 & 26.1 & 3.55 & 2.65 & 2.66 & 3.25 & 3.10 & 45.8 \\
\hline
\end{tabular}

\section{DISCUSSION OF RESULTS}

The fact that higher particle-density values were obtained in water than in nitrobenzene, a nonpolar liquid, is in close agreement with the findings of Anderson and Mattson (2) and, in general, with those of Smith (10) and Jamison, ${ }^{5}$ although the differences found by the latter two were considerably smaller. The differences between the results obtained with water and with nitrobenzene may be explained by orientation and consequent "packing" of the dipole water molecules on the surface of soil colloids $(2,8)$ or by failure to fill all the soil pores with nitrobenzene (5). In view of the pre-

- Personal communication of Vernon C. Jamison, Soil Scientist, Agricultural Research Service, USDA. 
TABLe 2.-Total porosity of undisturbed cores from 4 Puerto Rican soil types as determined by various methods

\begin{tabular}{|c|c|c|c|c|}
\hline \multirow[b]{2}{*}{ Soil and sample No. } & \multirow[b]{2}{*}{ Bulk density } & \multicolumn{3}{|c|}{ Total soil porosities obtained from- } \\
\hline & & $\begin{array}{l}\text { Bulk-density } \\
\text { and particle- } \\
\text { density data }\end{array}$ & $\begin{array}{l}\text { Air-picnometer } \\
\text { determinations } \\
\text { on dry cores }\end{array}$ & $\begin{array}{l}\text { Air-picnometer } \\
\text { determinations } \\
\text { on moist cores }\end{array}$ \\
\hline \multicolumn{5}{|l|}{ Catalina: } \\
\hline 1 & 1.20 & 54.7 & 59.5 & 60.3 \\
\hline 2 & 1.25 & 52.8 & 55.5 & 63.8 \\
\hline 3 & .92 & 65.2 & 67.5 & 69.2 \\
\hline 4 & 1.05 & 60.4 & 65.5 & 65.0 \\
\hline 5 & 1.22 & 54.0 & 57.5 & 58.7 \\
\hline 6 & .93 & 64.9 & 66.5 & 70.8 \\
\hline 7 & 1.05 & 60.4 & 66.5 & 63.2 \\
\hline 8 & 1.14 & 56.9 & 62.7 & 61.5 \\
\hline 9 & .99 & 62.6 & 67.5 & 64.7 \\
\hline 10 & .78 & 70.6 & 71.0 & 74.0 \\
\hline Average... & 1.05 & 60.2 & 64.0 & 65.1 \\
\hline \multicolumn{5}{|l|}{ Coto: } \\
\hline 1 & 1.10 & 58.5 & 68.0 & 61.6 \\
\hline 2 & 1.27 & 52.1 & 63.0 & 58.8 \\
\hline 3 & 1.11 & 58.1 & 68.0 & 64.0 \\
\hline 4 & 1.28 & 51.7 & 62.8 & 63.5 \\
\hline $\mathbf{5}$ & 1.09 & 58.9 & 68.5 & 65.4 \\
\hline 6 & 1.17 & 55.8 & 65.7 & 67.7 \\
\hline 7 & 1.08 & 59.2 & 69.0 & 65.0 \\
\hline 8 & 1.25 & 52.9 & 63.0 & 60.6 \\
\hline 9 & 1.07 & 59.6 & 69.0 & 65.6 \\
\hline 10 & 1.33 & 49.8 & 60.0 & 56.4 \\
\hline Average. . & 1.17 & 55.7 & 65.7 & 62.9 \\
\hline \multicolumn{5}{|l|}{ Toa: } \\
\hline 1 & 1.14 & 57.0 & 65.5 & 62.6 \\
\hline 2 & 1.11 & 58.1 & 65.7 & 65.0 \\
\hline 3 & 1.13 & 57.3 & 65.7 & 64.4 \\
\hline 4 & 1.03 & 61.1 & 70.0 & 66.4 \\
\hline 5 & 1.07 & 59.6 & 67.0 & 65.5 \\
\hline 6 & 1.13 & 57.3 & 67.0 & 66.0 \\
\hline 7 & 1.11 & 58.1 & 66.5 & 65.3 \\
\hline 8 & 1.07 & 59.6 & 68.5 & 65.4 \\
\hline 9 & 1.11 & 58.1 & 66.5 & 64.5 \\
\hline 10 & 1.21 & 54.3 & 64.5 & 59.0 \\
\hline Average & 1.11 & 58.0 & 66.7 & 64.4 \\
\hline
\end{tabular}


TABLE 2.-Continued

\begin{tabular}{c|c|c|c|c}
\hline & & \multicolumn{2}{|c}{ Total soil porosities obtained from- } \\
\cline { 3 - 5 } Soil and sample No. & Bulk density & $\begin{array}{c}\text { Bulk-density } \\
\text { and particle- } \\
\text { density data }\end{array}$ & $\begin{array}{c}\text { Air-picnometer } \\
\text { determinations } \\
\text { on dry cores }\end{array}$ & $\begin{array}{c}\text { Air-picnometer } \\
\text { determinations } \\
\text { on moist cores }\end{array}$ \\
\hline Fajardo: & & & & \\
1 & 1.18 & 55.5 & 65.0 & 60.3 \\
3 & 1.15 & 56.6 & 67.0 & 62.5 \\
4 & 1.18 & 55.5 & 65.5 & 60.8 \\
Average................. & 1.19 & 55.1 & 64.8 & 59.7 \\
\hline
\end{tabular}

cautions taken to assure complete saturation of the samples, the former explanation appears to be more plausible and the results with nitrobenzene more accurate.

The data seem to indicate that the kaolinitic soils high in clay content (Coto and Catalina) are capable of adsorbing water to the extent of about 1 percent of their weight. The high wilting points (1) found with these soils tend to lend further credence to this assumption. The relatively low particle-density values obtained in water with Toa soil may be explained by the low clay content of this soil, although it is of the expanding lattice type. Also, this type of clay may retain appreciable moisture even after drying at $105^{\circ} \mathrm{C}$. Thus, a given quantity of clay may have no more "effective" surface on which the water added in the picnometer could be "packed" than would an equal amount of kaolinitic clay.

The high particle-density and total-porosity values obtajned by the airpicnometer method using dry soil may be explained by gaseous adsorption on the surface of dry soil colloids while under pressure in the air picnometer, as shown by Jamison (3). Calculations made from these data indicate that an average of about $8 \mathrm{cc}$. of air were "sorbed" per $100 \mathrm{gm}$. of soil. This results in a lower volume of soil as determined by the air picnometer, and consequently in apparently higher particle densities and total porosities.

The particle-density and porosity values obtained by the air-picnometer method with moist soil cores, although generally somewhat lower than those obtained with dry soil, are still far too high. There appear to be two likely reasons for this. First, there may be considerable solution of air in soil moisture while under pressure in the air picnometer, resulting in errors analogous to those caused by gaseous adsorption on dry colloids. Calculations indicate that an average of about $5.5 \mathrm{cc}$. of air were "sorbed" per 100 $\mathrm{gm}$. of soil. Second, in correcting for the space occupied by water, the volume occupied by this liquid is calculated from weight data using a density 
value of 1 , although the actual density may be greater"due to orientation of the water molecules on colloidal surfaces, as discussed previously. Thus, the volume of water is overestimated, resulting in higher particle-density

TABLE 3.-The apparent" total porosity of and gaseous "sorption" by a Catalina clay soil at varying moisture contents as determined with the air picnometer ${ }^{2}$

\begin{tabular}{|c|c|c|c|c|c|c|c|}
\hline \multirow{2}{*}{ Item } & \multicolumn{7}{|c|}{$\begin{array}{l}\text { Results for soil of the indicated percentage moisture content, } \\
\text { by volume- }\end{array}$} \\
\hline & $\begin{array}{l}\text { Oven- } \\
\text { dried }\end{array}$ & 16.4 & 27.6 & 36.4 & 39.8 & 45.3 & 49.3 \\
\hline Apparent porosity........ percent & 64.2 & 64.8 & 61.9 & 61.7 & 63.3 & 63.4 & 64.1 \\
\hline Air "sorbed" per $100 \mathrm{gm}$. of soil. .cc. & 7.0 & 7.5 & 5.0 & 4.9 & 6.2 & 6.3 & 6.9 \\
\hline
\end{tabular}

1 True total porosity as calculated from bulk and particle-density data $=\mathbf{5 5 . 8}$.

2 All values are averages of 20 samples.

TABLE 4.-The effect of soil structure and percentage air-filled pore space on apparent volumes of soil-plus-water, "sorbed" air, and soil-particle density, as determined by the air picnometer on two clays ${ }^{1}$

\begin{tabular}{|c|c|c|c|c|c|}
\hline Soil and volume weight & $\begin{array}{l}\text { Air in } \\
\text { soil by } \\
\text { volume }\end{array}$ & $\begin{array}{l}\text { True } \\
\text { volume, soil- } \\
\text { plus-water }\end{array}$ & $\begin{array}{c}\text { Apparent } \\
\text { volume soil- } \\
\text { plus-water, } \\
\text { by air } \\
\text { picnometer }\end{array}$ & $\begin{array}{l}\text { "Sorbed" } \\
\text { air per } 100 \\
\text { gm. soil }\end{array}$ & $\begin{array}{l}\text { Particle } \\
\text { density of } \\
\text { soil as } \\
\text { determined } \\
\text { with air } \\
\text { picnometer }\end{array}$ \\
\hline & Percent & Cc. & Cc. & Cc. & \\
\hline $\begin{array}{l}\text { Hurricane clay, 44-percent } \\
\text { moisture by weight: }\end{array}$ & & & & & \\
\hline 0.50 & 59.5 & 190.4 & 179.8 & 4.50 & 3.08 \\
\hline .78 & 36.8 & 190.0 & 183.4 & 2.80 & 2.92 \\
\hline 1.21 & 2.4 & 189.3 & 190.8 & .62 & 2.66 \\
\hline $\begin{array}{l}\text { Decatur clay } 18 \text {-percent } \\
\text { moisture by weight: }\end{array}$ & & & & & \\
\hline 1.05 & 42.2 & 271.9 & 264.5 & 1.51 & 2.83 \\
\hline 1.25 & 31.3 & 271.9 & 265.8 & 1.22 & 2.80 \\
\hline 1.41 & 22.2 & 271.8 & 267.7 & .83 & 2.77 \\
\hline 1.69 & 6.4 & 271.7 & 268.9 & .63 & 2.76 \\
\hline
\end{tabular}

1 Unpublished data obtained by Charles W. Domby. All values are means of 5 replicates. Differences in apparent volume, "sorbed" air, and particle density are significant at the 1-percent level.

and total-porosity values. It should be noted, however, that the magnitude of the error thus introduced is small.

The only likely error in the porosity values calculated from bulk-density and particle-density data lies in assuming a particle density of 2.65 . In 
any case, the error is small since, even considering extreme values ( 2.60 and 2.75), the variation is only about 2 percent of the pore space.

There is appreciable variation in the soil-moisture values as determined with the air picnometer and those obtained by oven-drying the samples. However, values generally fell within 5 percent of those obtained by ovendrying. By calibrating the instruments for the different soils and by taking a sufficient number of samples, this method would seem to be accurate enough for many types of fieldwork. It would appear to be particularly useful when the approximate moisture level of a soil has to be determined immediately in the field.

As mentioned previously, solution of air in soil moisture while under pressure in the air picnometer would appear to be a reasonable explanation for the high porosity and particle-density values obtained with moist cores. The fact that the data in table 3 show no clear relationship between moisture content and apparent total porosities or gaseous "sorption" is not surprising, since other factors probably mask any relationship of this nature.

It appears likely that area of air-water interface is important in determining the extent of gaseous solution in water. Since the area of contact between water and air is proportionately greater at low moisture contents, this factor alone would greatly obscure any relationship between quantity of water and extent of gaseous solution.

The data obtained by Domby (table 4) appear to indicate that, as the percentage air volume is reduced by compression of the samples, thus decreasing the area of air-water interface, gaseous solution in soil moisture decreases markedly, resulting in more precise values for particle density as determined with the air picnometer. These data thus seem to indicate that the area of air-water interface is important in determining the extent of gaseous solution in soil moisture while under pressure in the air picnometer. Since the significant effect of compression disappeared when the soils were oven-dried, it appears that the distribution of soil moisture and not of the solid soil was the important factor.

There is another possible source of variation in picnometric determinations. Air trapped in blocked pores in the wet, compacted samples might have failed to change pressure during the picnometric measurements. Compression of trapped air must occur as a result of soil-moisture movement which is slow in compact samples. Also the pressure applied in the picnometer is low (about 0.4 atmosphere). Trapped air which did not change pressure would tend to give higher picnometer readings, thus compensating for the error caused by gaseous sorption and resulting in values that are closer to correct for particle density. 


\section{SUMMARY}

The air picnometer does not appear to be suitable for accurately determining either the particle density, the porosity, or the moisture content of soil samples. However, it appears well suited to making rapid, approximate field estimates of soil porosity and moisture status.

In dry soils, gaseous adsorption on the surface of dry colloids introduces a serious error in picnometric determinations. In moist soils gaseous solution in soil moisture while under pressure in the air picnometer and "packing" of water molecules on colloidal surfaces introduce a similar error.

Structure also exerts a marked influence on picnometric determinations either by modifying the area of air-water interface, thus affecting the amount of air dissolved in the soil moisture, or through the effect of structure on the quantity of air which may be trapped and thus not be subject to pressure changes during the determinations.

The air picnometer has various innate weaknesses. It must be checked constantly for leakage. Since changes in atmospheric pressure affect results, calibration curves must be prepared for use at different pressures. The air picnometer must also be recalibrated periodically as variations occur with usage.

Data are presented showing the results of particle-density, soil-porosity, and soil-moisture determinations made by various methods on several soils of Puerto Rico. The relative merits of the various methods are discussed.

\section{RESUMEN}

El picnómetro de aire no parece sur un instrumento adaptable para los análisis precisos de densidad de partícula, porosidad, o contenido de humedad del suelo. Sin embargo, parece ser adaptable a aproximaciones de campo en los análisis de porosidad y humedad de suelos.

En suelos secos, la absorción de gases por la superficie expuesta de los coloides, introduce errores apreciables en los análisis con este instrumento. Errores similares ocurren cuando se trata de suelos húmedos. En estos casos los errores se deben a la disolución de gases en la solución del suelo por efecto de la presión ejercida en el instrumento y a la orientación de moléculas de agua en la superficie de los coloides.

La estructura del suelo también ejerce su efecto en la precisión de los análisis, ya sea modificando el área de contacto entre el aire y el agua, variando así la cantidad de aire disuelto en la solución del suelo, o alterando la cantidad de aire aprisionada en los intersticios estructurales del suelo, que por tal razón no son sometidos a los cambios de presión que ocurren durante el análisis.

El picnómetro de aire adolece de varios defectos. Debe ser inspeccionado 
constantemente para corregir escapes de aire. Los resultados con este instrumento son afectados por cambios en la presión atmosférica, por lo que se hace indispensable preparar curvas de calibración para adaptarse a las distintas presiones. Este instrumento debe ser recalibrado periódicamente para corregir fluctuaciones resultantes del desgaste por el uso.

Se presentan datos mostrando el resultado de análisis de densidad de partícula, porosidad, y humedad, con diferentes suelos de Puerto Rico, usando varios métodos. Se discuten los méritos relativos a cada uno.

\section{LITERATURE CITED}

1. Abruña-Rodríguez, F., and Smith, R. M., Clay mineral type and related properties of some soils of Puerto Rico, Soil Sci., 76 (6) 411, 1953.

2. Anderson, M. S., and Mattson, S., Properties of the colloidal soil materials, USDA Bul. 1452, 1926.

3. Jamison, V. C., The significance of air absorption by soil colloids in picnometric measurements, Soil Sci. Soc. Amer. Proc. 17 17-9, 1953.

4. Kummer, F. A., and Cooper, A. W., Soil porosity determinations with the air pressure picnometer as compared with the tension method, Agr. Eng. 26 21-3, 1945.

5. Makower, B., Show, T. M., and Alexander, L. T., The specific surface and density of some soils and their colloids, Soil Sci. Soc. Amer. Proc. (1937) 2 101-8, 1938.

6. Page, J. B., Advantages of the pressure picnometer for measuring the pore space in soils, Soil Sci. Soc. Amer. Proc. (1947) 12 81-4, 1948.

7. Russell, M. B., A simplified air picnometer for field use, Soil Sci. Soc. Amer. Proc. (1949) 14 73-6, 1949.

8. Russell, E. W., Soil structure, Emp. Bur. Soil Sci. Tech. Commun. 37, 1948.

9. Smith, R. M., and Browning, D. R., Persistent water unsaturation of natural soils in relation to various soil and plant factors, Soil Sci. Soc. Amer. Proc. (1942) 7, 114-9, 1942.

10. Smith, W. O., Density of soil solids and their genetic relations, Soil Sci. 56 263-72, 1943.

11. Torstensson, G., and Erickson, S., A new method for determining the porosity of the soil, Soil Sci. 42 405-18, 1936.

12. Visser, W. C., Pore space determinations as a field method, Soil Sci. 44 467-80, 1937. 